\title{
Acute invasive rhinosinusitis case caused by Aspergillus flavus in two patients prediagnosed with mucormycosis
}

\author{
Müge Aslan ${ }^{1}$, Yasemin Öz², Özcan Bor ${ }^{3}$ Eren Gündüz ${ }^{4}$, Filiz Akşit ${ }^{5}$ \\ ${ }^{1}$ Microbiology Laboratory, Yozgat State Hospital, Yozgat, Turkey \\ ${ }^{2}$ Department of Microbiology, Faculty of Medicine, Eskişehir Osmangazi University, Eskisehir, Turkey \\ ${ }^{3}$ Department of Child Health and Disease, Faculty of Medicine, Eskişehir Osmangazi University, Eskisehir, Turkey \\ ${ }^{4}$ Department of Hematology, Faculty of Medicine, Eskişehir Osmangazi University, Eskisehir, Turkey \\ ${ }^{5}$ Retired lecturer, Eskisehir, Turkey
}

\begin{abstract}
Acute invasive rhinosinusitis caused by Aspergillus spp. may lead to invasive disease and mortality, especially in immunocompromised individuals. In this report, two invasive fungal rhinosinusitis cases in an immune compromised patient have been presented that were pre-diagnosed with mucormycosis, but with a positive culture for Aspergillus flavus. Twenty-four years old male patient with aplastic anemia and seven years old patient with acute lymphoblastic leukemia; facial pain, edema, and necrotic lesions developed in both cases. Tissue samples were obtained from lesions through the nose by biopsy for definitive diagnosis. Septate fungal hyphae observed on the microscopic examination of the specimen, and A. flavus was isolated in the culture in both cases. Surgical debridement could not be performed because of patients' general conditions. Despite antifungal therapy and treatments, patients died. Delay in diagnosis and treatment may lead to high mortality rates. These cases emphasize the importance of diagnosis with culture. $J$ Microbiol Infect Dis 2015;5(3): 137-141
\end{abstract}

Key words: Acute invasive fungal rhinosinusitis, Aspergillus flavus, diagnosis.

\section{Mukormikoz öntanılı iki olguda Aspergillus flavus'un neden olduğu akut invaziv rinosinüzit enfeksiyonu}

\section{ÖZET}

Aspergillus türlerinin neden olduğu akut invaziv fungal rinosinüzit; immünsüprese hastalarda mortaliteye yol açabilir.

Rinoserebral mukormikoza klinik olarak benzediğinden mukormikoz ön tanısı almış ancak kültürde etken olarak Aspergillus flavus üretilmiş iki invaziv fungal rinosinüzit olgusu bu raporda sunulmuştur. Aplastik anemi tanısıyla takip edilen 24 yaşındaki erkek hasta ve akut lenfoblastik lösemi tanısıyla izlenen yedi yaşındaki kız çocuğunda yüzde ağrı, ödem, ve burun çevresinde nekrotik lezyonlar mevcuttu. Antifungal tedaviye rağmen burunda nekroz gelişti. Tanı amacıyla burundaki lezyondan alınan biyopsi örneğinin mikroskobik incelemesinde septalı hifler görüldü ve kültürde iki olguda da $A$. flavus izole edildi. ỉki olgumuzda da gerekli tedaviler yapılmış olup cerrahi debridman hastaların genel durum bozukluğu nedeniyle yapılamadı ve antifungal tedaviye rağmen hastalar kaybedildi. İnvaziv fungal enfeksiyonlarda erken tanı ve tedavi hayati önem taşımaktadır. Bu olgular, fungal enfeksiyonların tanısında ve tedaviyi doğru şekilde yönlendirebilmede kültürün önemini vurgulaması açısından önemlidir.

Anahtar kelimeler: Akut invaziv fungal rinosinüzit, Aspergillus flavus, tanı

\section{INTRODUCTION}

Invasive fungal rhinosinusitis, being the infiltration of the mucosa of the nasal cavity and paranasal sinuses by fungal pathogens, a subtype of which is encountered less often and having a mortal course with a rapid progression, is referred to as acute invasive fungal rhinosinusitis (AIFR). AIFR may metastasize to the orbit or the cavernous sinus and cerebral parenchyma via the vasculature in immunosuppressed patients, presenting with progressive a course. The allergic grounds and mucosal 
thickening look seem to be the main predisposing factors in these patients. Long term antibiotherapy, steroid use, chronic bacterial sinusitis, presence of diseases such as uncontrolled diabetes mellitus, haematological malignancies with suppression or collapse of the immune system, patients receiving chemotherapy subsequent to bone marrow transplantation or aplastic anemia also constitute an important place in the risk group. ${ }^{1-7}$

The most frequently determined agents are Aspergillus spp. and the fungi in Mucorales species. It may abruptly result in death by virtue of vascular invasion by the pathogen and the resultant thrombotic ischemia. It is postulated to have a mortality rate in a range between $50-80 \%$.

Here, two invasive fungal rhinosinusitis cases have been presented that were prediagnosed with mucormycosis, but with a positive culture for $A$. flavus, because it clinically resembles rhinocerebral mucormycosis in which ischemia and necrosis remain at the forefront as a result of angio-invasion, which is clinically more precise within Mucorales members.

\section{CASE 1}

With an onset on the 37th day of hospitalization of a 24-year-old male patient with febrile neutropenia followed-up at the Haematology clinic diagnosed with aplastic anemia, swelling and hyperemia developed on the left side of his face with concomitant epistaxis on 30th day. In the laboratory examination of the patient, the white blood cell count was determined as $13.1 \mathrm{~K} / \mathrm{uL}(4.4-11.3) ; \mathrm{Hb}, 8.9 \mathrm{~g} / \mathrm{dl}$ (12.3-15.3); platelets, $607 \mathrm{~K} / \mathrm{uL}$ (150-450); fasting blood glucose, $284 \mathrm{mg} / \mathrm{dl}$ (70-115); urea $72 \mathrm{mg} / \mathrm{dl}$ (10-50); creatinine $1.68 \mathrm{mg} / \mathrm{dl}$ (0.6-1.3), erythrocyte sedimentation rate, $87 \mathrm{~mm} / \mathrm{h}(0-12)$; and CRP, 16 $\mathrm{mg} / \mathrm{L}(0-5)$. He received Piperacillin/Tazobactam and amikacin ten days followed by imipenem and teicoplanin. $200 \mathrm{mg}$ oral Voriconazole initiated on 40th hospitalization day; but changed it to i.v liposomal Amphotericin B 300mg/day; because of fever persistence and soft tissue density suggestive of fungal infection was observed in the left maxillary sinus on the paranasal magnetic resonance imaging (MRI) examination and on day 48 (Figure 1). Ubiquitous crusts through the nasal passage, black skin lesions and nasal necrosis developed despite antifungal therapy. Taking into consideration the mucormycosis, biopsy was conducted on the lesion with the purpose of definitive diagnosis and subsequently, the treatment was switched to posaconazole (4 x $200 \mathrm{mg} / \mathrm{oral}$ form) on 60th hospitalization day. Structures with septate hyphae were observed on the microscopic examination of the biopsy specimen (Figure 2-3). Aspergillus flavus was isolated from the culture of this specimen (Figure 4). The results of in vitro antifungal susceptibility with $E$ test method were found to be $6.00,1.00,4.00 \mu \mathrm{g} / \mathrm{mL}$ for amphotericin B, voriconazole and itraconazole, respectively. With regard to this case, GM antigen was detected positive consecutively two times $(0.58$ and 0.62 indexes) on 65 and 69th day; which was performed within the varying intervals of hospitalization. Surgical debridement could not be performed due to the patient's general condition, and he died on the 75th day of hospitalization.

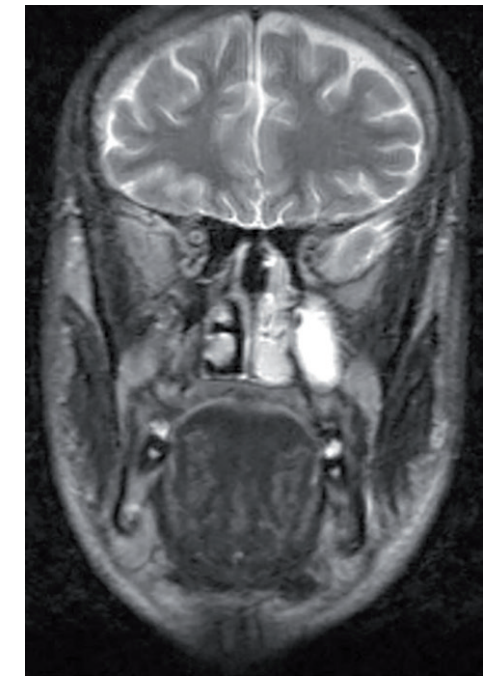

Figure 1. Brain magnetic resonance imaging (T1-weighted, transversal view) shows a soft tissue density in the left maxillary sinus.

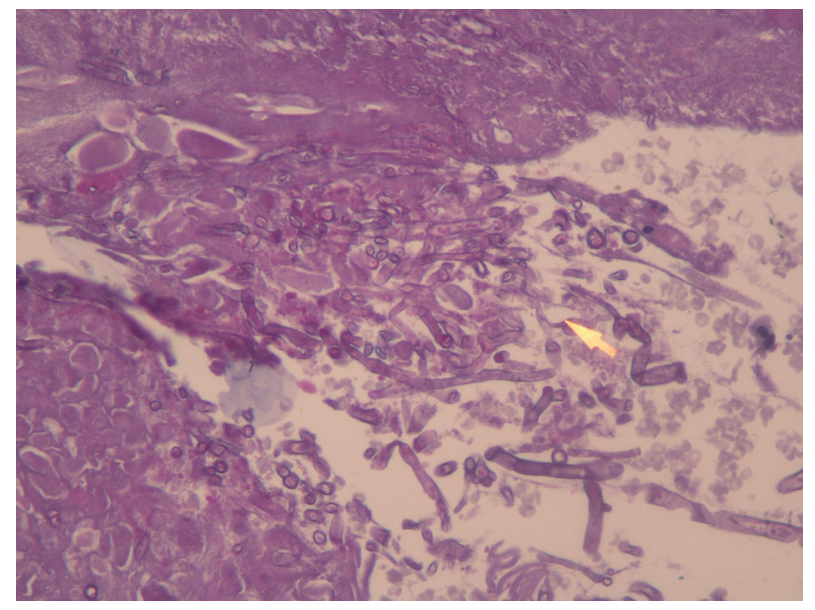

Figure 2. Fungal hyphae in the chronically inflammated stroma and the lumens of small diameter vessels on the histopathological examination carried out by PAS staining (x400). 


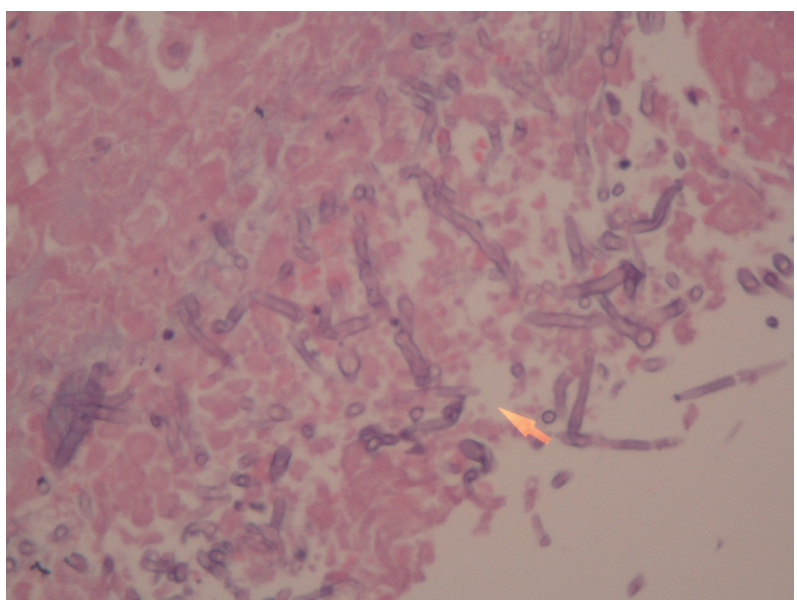

Figure 3. Fungal hyphae on the necrotic background on the histopathological examination carried out by $\mathrm{H}$ \& $\mathrm{E}$ staining (x400).

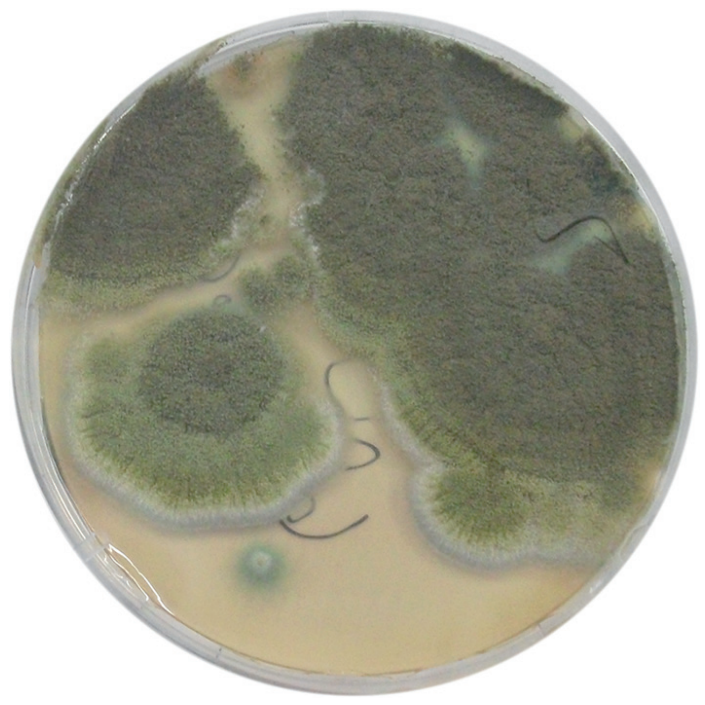

Figure 4. Three-day A. flavus colonies in SDA

\section{CASE 2}

In a 7-year-old patient followed-up in the pediatric haematology clinic, diagnosed with refractory and relapsing acute lymphoblastic leukemia (ALL), in the period of febrile neutropenia, a necrotic lesion appeared that was suggestive of mucormycosis on the right side of the nose in addition to swelling of the right eye and edema on the right side of her face. She received Piperacillin/Tazobactam and amikacin fourteen days followed by an imipenem. The results of paranasal and orbital MRI carried out for the diagnosis were consistent with fungal infection. Liposomal amphotericin B (5 mg/kg intravenously daily) treatment was initiated on 45th day, but surgical debridement could not be performed because the patient's general condition was impaired. Suggestive of the prediagnosis of mucormycosis, a tissue sample was obtained from the lesion through the nose by biopsy for the purpose of the definitive diagnosis. Septate fungal hyphae were observed on the microscopic examination of the specimen and A. flavus was isolated in the culture on $57^{\text {th }}$ day. The results of in vitro antifungal susceptibility test with $E$ test were found to be $0.047,0.25$ and $0.047 \mu \mathrm{g} / \mathrm{mL}$ for amphotericin B, voriconazole and itraconazole, respectively. GM positivity detected one time with 0.52. The patient died on the 62th day of the infection in spite of the chemotherapy, broad spectrum antibacterial and antifungal therapy.

\section{DISCUSSION}

Intensive and prolonged term use of modern chemotherapeutics in haematological malignancies during the recent years has ensured successful results in primary disease. On the other hand, long term neutropenia, which is induced by chemotherapy, increases the incidence of invasive fungal infections in these patients. The majority of the cases with acute fulminant sinusitis presented in the literature are comprised of patients with haematological malignancies. One of our patients was followed-up with the diagnosis of aplastic anemia, and the latter had ALL. When nasal cavity and paranasal sinuses are affected by invasive fungal infections, first, mucosal paling depending on ischemia and subsequently, gray discoloration and black crusts will be observed depending on the necrosis. The commonly encountered symptoms are fever (44\%), nasal ulceration and black necrotic tissue in the nose $(38 \%)$, periorbital and facial edema $(34 \%)$, vision disorders $(30 \%)$, headache $(25 \%)$, and facial pain $(22 \%)$. While headache was present in one of the cases on presentation, proptosis, fever, nausea and periorbital cellulitis developed during the following days. Facial pain, edema, vision disorders and necrotic lesions were present in both cases.

The use of radiological imaging methods, CT and MRI demonstrate an infiltration, destruction and frequently, invasion to the contiguous tissues. However, these findings may be confounded by other factors such as mucormycosis, vascular diseases, and benign/malignant tumors. ${ }^{5,8-10}$ It has been pointed out that the soft tissue lesion filling the sphenoidal sinus and destroying the bone structure and also extending to the nasal cavity and supracellular 
cisterna on MRI examinations of our cases may be consistent with fungal infection. Most patients do not have classic findings in the early phase of infection.

With regard to the definitive diagnosis, it is made by observing fungal hyphae in the tissue specimens. Biopsy sampling must be conducted on suspected nasal or oral mucosal lesions. Tissue samples must be received if possible and stains such as hematoxylin and eosin (HE), Gomorimethenamine silver (GMS) and periodic acid-Schiff (PAS) are useful for identifying the fungi. Furthermore, the sample must be cultured in a suitable medium. The diagnosis in our cases was made by reproducing the agent and in one case by observing fungal hyphae histopathologically. In both cases, A. flavus was reproduced as the etiologic agent.

It has been reported that studying GM antigen may be helpful for the early diagnosis of invasive fungal infections. ${ }^{9}$ In both cases, GM antigen was detected as positive, which was performed within the varying intervals as from the time of hospitalization.

Early and aggressive treatment is required in invasive fungal sinusitis. Since the acute fulminant disease may result in death within days or even hours, debridement of the overall necrotic tissue is recommended right after diagnosis in order to diminish the fungal burden. It is ascertained that amphotericin $B(A M B)$ intravenously and treating the underlying disease is complementary to surgery and bringing the ketoacidosis under control rapidly in patients with diabetes mellitus enhances survival. It has been reported that although amphotericin B treatment of sinusitis by Aspergillus spp. in patients with leukemia, there are studies in which alternative antifungal agents are used. ${ }^{11}$ In the literature, the survival rates vary depending on the underlying etiology, ante-mortem diagnosis, and treatment. ${ }^{1,3,6}$

In both of our cases, the treatments required for haematological diseases, which were considered predisposing conditions, were applied. Surgical debridement could not be performed due to impairment in the patients' general conditions, and the patients died despite the systemic amphotericin B treatment.

In conclusion, acute invasive fungal rhinosinusitis is a severe infection affecting immunodeficient individuals, and it has a fatal course. The agents are frequently the fungi which are members of the Aspergillus and Mucorales species. Both fungal agents display similar clinical features. We also prediagnosed our cases as mucormycosis with clinical signs and symptoms. For this reason, microscopy and culture should be performed for the definitive diagnosis. Radiology, direct microscopy, and histopathological examination carried out for fungal infection.

Compared to mucormycosis, which involves non-septate hyphae and right-angle branching, aspergillosis shows septate hyphae with 45 branches. However, other hyalohyphomycetes, for example, Fusarium, and Pseudallecheria boydii, have similar histological characteristics to Aspergillus. Microbiological cultures provide a definitive diagnosis and distinguish other possible fungal pathogens. Not only Mucorales spp. are resistant most of antifungal agents but also Aspergillus spp. are susceptible some of them. In presented cases, A. flavus was isolated from the culture, and antifungal susceptibility test performed. It was most important point of these cases; because of definitive diagnosis and treatment strategy of fungal rhinosinusitis. The nonspecific onset of the infections, rapid and fatal course, and the impairment in the patients' general conditions are the most important reasons for limitation of diagnosis. Symptoms and signs such as nose ulceration, eschar of the nasal mucosa, black necrotic lesions are more specific, but these findings are present only at an advanced stage. When the manifestations of sinusitis are viewed in patients with immunosuppression, fungal sinusitis must be taken into consideration.

These cases are important to emphasize the significance of culture in the definitive diagnosis of fungal infections.

\section{Acknowledgment}

Presented at 1. International Medical Mycology Symposium on 26-27 April 2013, Izmir /Turkey Poster Presentation 18.

\section{REFERENCES}

1. DelGaudio JM, Clemson LA. An Early Detection Protocol for Invasive Fungal Sinusitis in Neutropenic Patients Successfully Reduces Extent of Diseases at Presentation and Long Term Morbidity. The Laryngoscope 2009;119:180-183.

2. Suslu AE, Ogretmenoglu O, Suslu N, et al. Acute invasive fungal rhinosinusitis: our experience with 19 patients. Eur Arch Otorhinolaryngol 2009;266:77-82.

3. Takahashi $\mathrm{H}$, Hinohira $\mathrm{Y}$, Hato $\mathrm{N}$, et al. Clinical features and outcomes of four patients with invasive fungal sinusitis. Auris Nasus Larynx 2011;38:289-294.

4. Montone KT, Virginia A Livolsi VA, et al. Fungal Rhinosinusitis: A retrospective microbiologic and pathologic review of 400 patients at a single university medical center. Int J Otolaryngol 2012:684835. 
5. Beltrame A, Sarmati L, Cudillo L, et al. A fatal case of invasive fungal sinusitis by Scopulariopsis acremonium in a bone marrow transplant recipient. Int J Infect Dis 2009;13:488492.

6. Valera FCP, do Lago T, Tamashiro E, et al. Prognosis of acute invasive fungal rhinosinusitis related to underlying disease Int J Infect Dis 2011;15:841-844.

7. Kasapoglu F, Coskun H, Ozmen OA, et al. Acute invasive fungal rhinosinusitis: Evaluation of 26 patients treated with endonasal or open surgical procedures. Otolaryngology-Head and Neck Surgery 2010;143:614-620.

8. Chen $\mathrm{CY}$, Sheng $\mathrm{WH}$, Cheng $\mathrm{A}$, et al. Invasive fungal sinusitis in patients with hematological malignancy: 15 years experi- ence in a single university hospital in Taiwan. BMC Infectious Diseases 2011;11:250.

9. Hachem RY, Kontoyiannis DP, Chemaly RF, et al. Utility of galactomannan enzyme immunoassay and $(1,3)$ beta-D-glucan in diagnosis of invasive fungal infections: low sensitivity for Aspergillus fumigatus infection in hematologic malignancy patients. J Clin Microbiol 2009;47:129-133.

10. Mossa-Basha M, llıca AT, Maluf F, et al. The many faces of fungal disease of the paranasal sinuses: CT and MRI findings. Diagn Interv Radiol 2013;19:195-200.

11. Thomas JW, Elias JA, David WD, et al. Treatment of aspergillosis: Clinical practice guidelines of the infectious disease society of America. Clin Infect Dis 2008;46:327-360. 